\title{
INFLUENCE OF PRECIPITATION CONDITIONS ON THE SYNTHESIS OF HYDROXYAPATITE
}

\author{
"LENKA ŠIMKOVÁ, NATALIIA GORODYLOVA, ŽANETA DOHNALOVÁ, PETRA ŠULCOVÁ \\ Department of Inorganic Technology, Faculty of Chemical Technology, University of Pardubice, \\ Doubravice 41, 53210 Pardubice, Czech Republic \\ "E-mail: st38312@student.upce.cz
}

Submitted January 5, 2018; accepted March 27, 2018

\begin{abstract}
Keywords: Hydroxyapatite, Precipitation, Calcium/phosphate ratio, XRD, SEM
The goal of this study was to find suitable precipitation conditions (Ca/P ratio, $\mathrm{pH}$ and precipitation rate) for the synthesis of hydroxyapatite ( $\left.\mathrm{HAP} ; \mathrm{Ca}_{10}\left(\mathrm{PO}_{4}\right)_{6}(\mathrm{OH})_{2}\right)$ and to determine the effect of precipitation conditions on the product properties. Hydroxyapatite was synthesized by precipitation. Three ratios of $C a / P(1 ; 1.67 ; 3)$ were selected for the synthesis, then two $\mathrm{pH}$ values (7 and 12) and two precipitation rates of ammonium dihydrogen phosphate $\left(0.5\right.$ and $\left.5 \mathrm{ml} \cdot \mathrm{min}^{-1}\right)$. The prepared powders were evaluated from the standpoint of particle size distribution, crystal size and morphology by optical and scanning electron microscope, and phase composition by X-ray diffraction analysis.
\end{abstract}

\section{INTRODUCTION}

The term "apatite" applies to a group of compounds (not only at calcium phosphates) with a general formula in form $\mathrm{M}_{10}\left(\mathrm{XO}_{4}\right)_{6} \mathrm{Z}_{2}$, where $\mathrm{Z}^{-}$may be typically $\mathrm{OH}^{-}$, $\mathrm{F}^{-}, \mathrm{Cl}^{-}$. The cationic positions of $\mathrm{M}^{2+}$ can be completely or partially replaced by the $\mathrm{Sr}^{2+}, \mathrm{Ba}^{2+}, \mathrm{Pb}^{2+}, \mathrm{Na}^{+}$, etc. The apatite phosphate grid $\mathrm{XO}_{4}{ }^{3-}$ is highly tolerant to substitution and can be replaced by the $\mathrm{CO}_{3}^{2-}, \mathrm{HPO}_{4}^{2-}$, $\mathrm{AsO}_{4}{ }^{3-}, \mathrm{SiO}_{4}{ }_{4}^{2-}$ or $\mathrm{VO}_{4}{ }^{3-}$ groups. [1]. The particular name of each apatite depends on the elements $\mathrm{M}, \mathrm{X}$ and $\mathrm{Z}$. In these terms, hydroxyapatite (HAP) has the molecular structure of apatite, where $\mathrm{M}$ is calcium $\left(\mathrm{Ca}^{2+}\right), \mathrm{X}$ is phosphorus $\left(\mathrm{P}^{5+}\right)$ and $\mathrm{Z}$ is the hydroxyl group $\left(\mathrm{OH}^{-}\right)$. It is known as stoichiometric hydroxyapatite and its atomic ratio $\mathrm{Ca} / \mathrm{P}$ is 1.67. Its chemical formula is $\mathrm{Ca}_{10}\left(\mathrm{PO}_{4}\right)_{6}(\mathrm{OH})_{2}$, with $39 \%$ by weight of $\mathrm{Ca}, 18.5 \% \mathrm{P}$ and $3.38 \%$ of OH $[2,3]$.

Nowadays, significant attention is paid to the use of hydroxyapatite, especially in the field of orthopedics, where these phosphates can replace bone tissue either partially or totally $[4,5]$. With respect to hydroxyapatite $\left(\mathrm{Ca}_{10}\left(\mathrm{PO}_{4}\right)_{6}(\mathrm{OH})_{2}, \mathrm{HAP}\right)$, it is an important technological material. One of its applications includes its use on metal implants as a coating which has two important functions: on one hand to protect the implant against corrosion, and on the other hand, to improve implant's biocompatibility with the human body $[2,6]$. In view that HAP is suitable for the protection of the implants against corrosion due to its both structural and physical-chemical properties, it can be also functional in steel anticorrosion protection like other phosphates [4].
Chemical stability of apatites is influenced by the apatite composition and synthesis method which also affects crystal size and morphology. Hydroxyapatite can be manufactured synthetically by using a number of different methods [7, 8]. The processes for the preparation of hydroxyapatite and any other calcium phosphate powders may be classified under two main groups: synthesis from mammal bones or coral and in the laboratory, in this case, it can be synthesized by reactions in solid state [9], coprecipitation [10, 11], hydrothermal methods [12], sol-gel process [13, 14], microwave processing [15], and other [16].

The most common methods are chemical coprecipitation from water solutions containing the ions of $\mathrm{Ca}^{2+}, \mathrm{PO}_{4}^{3-}$, and $\mathrm{OH}^{-}$, which in conditions of $\mathrm{pH}>7$, form primary crystallites of insoluble hydroxyapatite [16]. There are typically two types of process in the wet method: one involves the reaction of calcium salts and phosphate salts (as it is described in this paper)

$$
\begin{aligned}
& 10 \mathrm{Ca}\left(\mathrm{NO}_{3}\right)_{2} \cdot 4 \mathrm{H}_{2} \mathrm{O}+6\left(\mathrm{NH}_{4}\right) \mathrm{H}_{2} \mathrm{PO}_{4}+8 \mathrm{NH}_{4} \mathrm{OH} \rightarrow \\
& \rightarrow \mathrm{Ca}_{10}\left(\mathrm{PO}_{4}\right)_{6}(\mathrm{OH})_{2}+20 \mathrm{NH}_{4} \mathrm{NO}_{3}+46 \mathrm{H}_{2} \mathrm{O}
\end{aligned}
$$

and, the other involves the neutral reaction of an acid and alkaline solutions [17].

The objective of this work is the synthesis of hydroxyapatite powders by the precipitation method with different $\mathrm{Ca} / \mathrm{P}$ ratios, $\mathrm{pH}$ and the rate of precipitation of ammonium dihydrogen phosphate. Three ratios of $\mathrm{Ca} / \mathrm{P}=1 ; 1.67$ and 3 were selected; two $\mathrm{pH}$ values of 7 and 12 , where ammonia hydroxide solution was used 
to adjust the $\mathrm{pH}$; and two precipitation rates of 0.5 and $5 \mathrm{ml} \cdot \mathrm{min}^{-1}$. The synthesized powders were characterized by X-ray diffraction in order to identify the phase composition and crystallinity; the morphology of synthesized powders has been studied by scanning electron microscopy (SEM), the dimension of the crystals has been studied by an optical microscope (digital and projection microscope) and the synthesized powders were analyzed for particle size distribution.

\section{EXPERIMENTAL}

\section{Materials}

$\mathrm{Ca}\left(\mathrm{NO}_{3}\right)_{2} \cdot 4 \mathrm{H}_{2} \mathrm{O}(98 \%$, Lachema, Czech Republic), $\left(\mathrm{NH}_{4}\right) \mathrm{H}_{2} \mathrm{PO}_{4}$ (98\%, Lachema, Czech Republic), $\mathrm{NH}_{4} \mathrm{OH}$ (25\%, Penta Chrudim, Czech Republic) were used for wet precipitation method. For the synthesis of hydroxyapatite, solutions of starting materials $\left(\mathrm{Ca}\left(\mathrm{NO}_{3}\right)_{2} \cdot 4 \mathrm{H}_{2} \mathrm{O}, \quad\left(\mathrm{NH}_{4}\right) \mathrm{H}_{2} \mathrm{PO}_{4}\right)$ of $1 \mathrm{~mol} \cdot \mathrm{l}^{-1}$ were prepared. The precise concentrations of these solutions were determined using analytical methods.

\section{Chemical analysis of starting materials}

Determination of calcium concentration was performed by chelation method. A solution of chelation III (EDTA) was prepared, by accurate weighing $4.653 \mathrm{~g}$ of EDTA on the analytical scales. The weight was transferred to a $250 \mathrm{ml}$ volumetric flask, dissolved in distilled water and added along the line. Because EDTA is a basic substance and has been weighed accurately, no factor has to be determined. Eirchrome black T was chosen as the indicator, which was prepared by weighing $0.3046 \mathrm{~g}$ of eirchromatic black $\mathrm{T}$ and then dissolved in a solution of $25 \mathrm{ml}$ of propanol and $15 \mathrm{ml}$ of triethanolamine. To adjust the $\mathrm{pH}$, a $30 \%$ sodium hydroxide solution was prepared. Calcium nitrate titration test was performed as follows: $10 \mathrm{ml}$ of a cold $1000 \mathrm{mg} \mathrm{Ca} / 1000 \mathrm{ml}$ calcium stock solution was taken up to $10 \mathrm{ml}$ in a titration flask, adjusted to $\mathrm{pH} 13$ with $30 \%$ sodium hydroxide, then $5 \mathrm{ml}$ of $50 \%$ a solution of triethanolamine and about 20 drops of the Eirochrome black $\mathrm{T}$ indicator. The solution was titrated with a standard solution of EDTA until the change from purple to blue color.

Phosphorus concentration was determined by the photometric method. The photometric measurement of the phosphorus content is based on the determination of the concentration of the heteropolyacid into which the phosphorus contained in the sample should be transformed. Phosphorus determination as vanadium molybdate phosphoric acid is a fast, reliable and simple method. Orthophosphates react with mineral acids, such as $\mathrm{HClO}_{4}$, with $\mathrm{VO}^{3-}$ and $\mathrm{MoO}_{4}{ }^{2-}$ ions to form yellow vanadate molybdate phosphoric acid. The preparation of the calibration and measuring solutions was carried out as follows: $0.5,1 ; 1,5 ; 2$ and $2.5 \mathrm{ml}$ of standard phosphorus solution were pipetted into $50 \mathrm{ml}$ volumetric flasks. Then $5 \mathrm{ml}$ of solution A and $10 \mathrm{ml}$ of solution $\mathrm{B}$ were added to each volumetric flask. Solution A was prepared by diluting $500 \mathrm{ml}$ of concentrated $\mathrm{HClO}_{4}$ into 1 liter with distilled water. Solution B was prepared by dissolving $1.17 \mathrm{~g}$ of $\mathrm{NH}_{4} \mathrm{VO}_{3}$ in $150 \mathrm{ml}$ of hot water and $35.2 \mathrm{~g}$ of $\left(\mathrm{NH}_{4}\right)_{6} \mathrm{Mo}_{7} \mathrm{O}_{24} \cdot 4 \mathrm{H}_{2} \mathrm{O}$ in $500 \mathrm{ml}$ of hot distilled water. Both solutions were mixed and $20 \mathrm{ml}$ of concentrated $\mathrm{NH}_{4} \mathrm{OH}$ was added with stirring and the volume was added along the line to 11 of distilled water. After the calibration solutions were prepared, a blank was prepared and the volumes in the flasks were added along the line to $50 \mathrm{ml}$ of distilled water and the contents allowed to stand for 10 minutes. The calibration solutions were then measured spectrophotometrically. One of the cuvettes presented was filled with a blank and the other was filled with the sample. A cuvette with a measured sample was inserted into the spectrophotometer Jenis 722-2000 (Perlong, China), the rod on the front of the instrument was inserted into the optical path and the absorbance reading was read on the display.

\section{Synthesis of HAP}

In order to select suitable synthesis conditions for hydroxyapatite phase formation, the thermodynamic stability of hydroxyapatite in aqueous solution was analyzed [18]. Figure 1 shows the predominance area diagram for the $\mathrm{Ca}^{2+}-\mathrm{PO}_{4}{ }^{3-}$ water system at $25^{\circ} \mathrm{C}$.

The $\mathrm{x}$-axis shows a $\mathrm{pH}$ scale ranging from 0 to 14 and the y-axis shows the decimal logarithm of the phosphate ions concentration. From the figure it is obvious that hydroxyapatite is stable in the $\mathrm{pH}$ range from 4.8 to 14 . Due to this information, three $\mathrm{Ca} / \mathrm{P}$ ratios

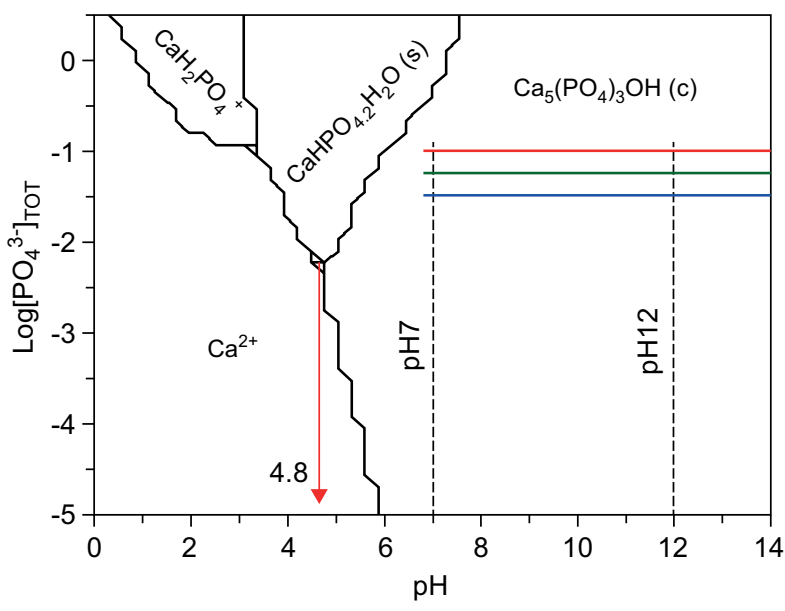

\footnotetext{
$-\mathrm{Ca} / \mathrm{P}=1,\left[\mathrm{PO}_{4}{ }^{3-}\right]_{\mathrm{TOT}}=0.1 \mathrm{M}, \log \left[\mathrm{PO}_{4}{ }^{3-}\right]_{\mathrm{TOT}}=-1$ $\mathrm{Ca} / \mathrm{P}=1.67,\left[\mathrm{PO}_{4}{ }^{3-}\right]_{\text {TOT }}=0.06 \mathrm{M}, \log \left[\mathrm{PO}_{4}{ }^{3-}\right]_{\text {TOT }}=-1.22$ $\mathrm{Ca} / \mathrm{P}=3,\left[\mathrm{PO}_{4}{ }^{3-}\right]_{\mathrm{TOT}}=0.033 \mathrm{M}, \log \left[\mathrm{PO}_{4}{ }^{3-}\right]_{\mathrm{TOT}}=-1.48$
}

Figure 1. Predominance area diagram for the $\mathrm{Ca}^{2+}-\mathrm{PO}_{4}{ }^{3-}$ system. 
were chosen for the synthesis of hydroxyapatite, which were studied at $\mathrm{pH}=7$ and $\mathrm{pH}=12$ based on the area of the hydroxyapatite form:

- $\mathrm{Ca} / \mathrm{P}=1$; when the equilibrium phosphate ions concentration is equal to $0.1 \mathrm{~mol} \cdot \mathrm{l}^{-1}$ and the decimal logarithm of this equilibrium concentration is -1 . In this case, HAP formation occurs in excess of phosphate ions.

- $\mathrm{Ca} / \mathrm{P}=1.67$; where the equilibrium phosphate ion concentration is equal to $0.06 \mathrm{~mol} \cdot \mathrm{l}^{-1}$ and the decimal logarithm of this equilibrium concentration is -1.22 . In this case, this corresponds to the $\mathrm{Ca} / \mathrm{P}$ stoichiometry of hydroxyapatite, which is $10 / 6$.

- $\mathrm{Ca} / \mathrm{P}=3$; when the equilibrium phosphate ions concentration is equal to $0.033 \mathrm{~mol} \cdot \mathrm{l}^{-1}$ and the decimal logarithm of this equilibrium concentration is -1.48 . In this case, HAP formation occurs in excess of calcium ions.

12 samples were prepared (Table 1) for which the $\mathrm{Ca} / \mathrm{P}$ molar ratio was maintained at $1 ; 1.67 \mathrm{a} 3$. All samples were prepared by precipitation. The calcium nitrate tetrahydrate solution $\left(\mathrm{Ca}\left(\mathrm{NO}_{3}\right)_{2} \cdot 4 \mathrm{H}_{2} \mathrm{O}\right)$ as a source of calcium, was heated to $50-70^{\circ} \mathrm{C}$ and ammonium dihydrogen phosphate $\left(\left(\mathrm{NH}_{4}\right) \mathrm{H}_{2} \mathrm{PO}_{4}\right)$ as a phosphorus source was added dropwise via the automatic titrator. The rate of addition of ammonium dihydrogen phosphate was 0.5 and $5 \mathrm{ml} / \mathrm{min}$. To keep a $\mathrm{pH}$ of 7 or 12 , an ammonia hydroxide solution was added and the $\mathrm{pH}$ value of the solution was measured during the synthesis by $\mathrm{pH}$ meter. After mixing the starting compounds, the precipitates were analyzed by an optical microscope (digital and projection microscope). The mixtures were stirred for 2 hours followed by aging for 24 hours. After 24 hours aging, specimens were analyzed by optical microscopy (digital and projection microscope) and particle size measurements by Mastersizer. Subsequently, the prepared samples were filtered based on the Buchner system and washed with distilled water to neutral $\mathrm{pH}$. This

Table 1. Overview of synthesized samples and their synthesis conditions.

\begin{tabular}{cccc}
\hline Sample & Ratio Ca/P & $\begin{array}{c}\text { Precipitation rate } \\
{\left[\mathrm{ml} \cdot \mathrm{min}^{-1}\right]}\end{array}$ & $\mathrm{pH}$ \\
\hline 1 & 1 & 5 & 7 \\
2 & $\mathrm{I} .67$ & 5 & 7 \\
3 & 3 & 5 & 7 \\
\hline 4 & 1 & 5 & 12 \\
5 & $\mathrm{I} .67$ & 5 & 12 \\
6 & 3 & 5 & 12 \\
\hline 7 & 1 & 0.5 & 7 \\
8 & $\mathrm{I} .67$ & 0.5 & 7 \\
9 & 3 & 0.5 & 12 \\
\hline 10 & 1 & 0.5 & 12 \\
11 & $\mathrm{I} .67$ & 0.5 & 12 \\
12 & 3 & 0.5 & \\
\hline
\end{tabular}

was followed by drying in a laboratory drying room (Memmert UNB 500, Germany) at $80^{\circ} \mathrm{C}$ for 6 hours. After drying, the powders was grinded in the laboratory mill Pulverisette 2 (Fritsch, Germany) and then in a agate mortar. An analysis of the prepared powders was then performed by SEM and XRD analysis.

\section{Characterization of $H A P$}

The size of the crystals can be measured and characterized by OM, SEM and the crystallinity and phase composition of the synthesized powders can be characterized by XRD.

\section{XRD analysis}

The phase analysis of the powdered materials was studied by X-ray diffraction analysis (XRD). The phase composition was determined using diffractometer MiniFlex 600 (Rigaku, Japan) equipped with a vertical goniometer of $17 \mathrm{~cm}$ in the $2 \theta$ range of $10^{\circ}-50^{\circ}$. The accuracy of goniometer was $\pm 0.02^{\circ}$. X-ray tube with $\mathrm{Cu}$ anode $(\mathrm{U}=40 \mathrm{kV}, \mathrm{I}=15 \mathrm{~mA})$ was used ( $\mathrm{CuK} \alpha$ radiation $)$.

\section{Optical microscope (OM)}

The dimension of the crystals was studied by two types of optical microscopes - digital (Dino-Lite Rack, AnMo Electronics, Taiwan) with magnification 10× $70 \times$ and $200 \times$ and projection (MP-1326, Poland) with magnification up to $1000 \times$.

\section{Measuring particle size distribution}

The particle size distribution of the synthesized powders was measured using an equipment Mastersizer 2000/MU (Malvern Instruments, Ltd., UK). This device provides volumetric distribution and uses the laser diffraction on particles dispersed in a liquid medium. The particle size distribution was analyzed by two lasers: red light (He-Ne laser with wavelength $633 \mathrm{~nm}$ ) and blue light (laser diode with wavelength $466 \mathrm{~nm}$ ). The pigments were ultrasonically (Bandelin, Germany) homogenized in the solution of $\mathrm{Na}_{4} \mathrm{P}_{2} \mathrm{O}_{7}\left(\mathrm{c}=0.15 \mathrm{~mol} \cdot \mathrm{dm}^{-3}\right)$ for $120 \mathrm{~s}$. The signal was evaluated on the basis of Mie scattering. The measurement is taken in three steps, and results are automatically calculated as average and presented as $\mathrm{d}_{10}$, $\mathrm{d}_{50}$, and $\mathrm{d}_{90}$ values.

\section{SEM analysis}

The morphology of synthesized powders was studied by scanning electron microscopy (SEM). Scanning Electron Microscopy (SEM) uses a scanning electron microscope. The resulting image is formed by the secondary signal - reflected or secondary electrons. The morphology of the prepared powder was determined using an electron microscope equipped with an IXRF Systems analyzer and a Gresham Sirius 10 detector (Joel Inc., USA). 


\section{RESULTS AND DISCUSSION}

\section{Optical microscope}

In order to observe changes in specimen morphology, samples were measured immediately after precipitation, then 2 hours and 24 hours after aging. Figure 2 shows the standard appearance of samples after aging. Some samples showed well-shaped crystals before aging,

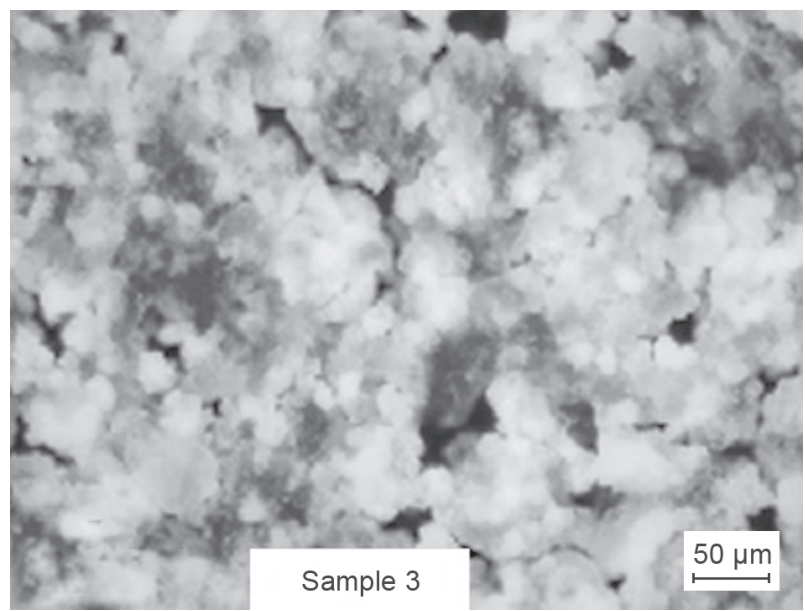

a) which are shown in table 2. For comparison, samples 3 $\left(\right.$ ratio $\left.\mathrm{Ca} / \mathrm{P}=3 ; \mathrm{pH}=7 ; 5 \mathrm{ml} \cdot \mathrm{min}^{-1}\right), 8($ ratio $\mathrm{Ca} / \mathrm{P}=$ $\left.=1.67 ; \mathrm{pH}=7 ; 0.5 \mathrm{ml} \cdot \mathrm{min}^{-1}\right)$ and $11($ ratio $\mathrm{Ca} / \mathrm{P}=1.67$; $\left.\mathrm{pH}=12 ; 0.5 \mathrm{ml} \cdot \mathrm{min}^{-1}\right)$ were selected, for which the most interesting crystals on the optical microscope were observed. In many samples after aging, agglomerates of very small crystals were observed, which are visible in Figure 2 (sample 3: ratio $\mathrm{Ca} / \mathrm{P}=3 ; \mathrm{pH}=7 ; 5 \mathrm{ml} \cdot \mathrm{min}^{-1}$; sample 5: ratio $\mathrm{Ca} / \mathrm{P}=1.67 ; \mathrm{pH}=12 ; 5 \mathrm{ml} \cdot \mathrm{min}^{-1}$ ).

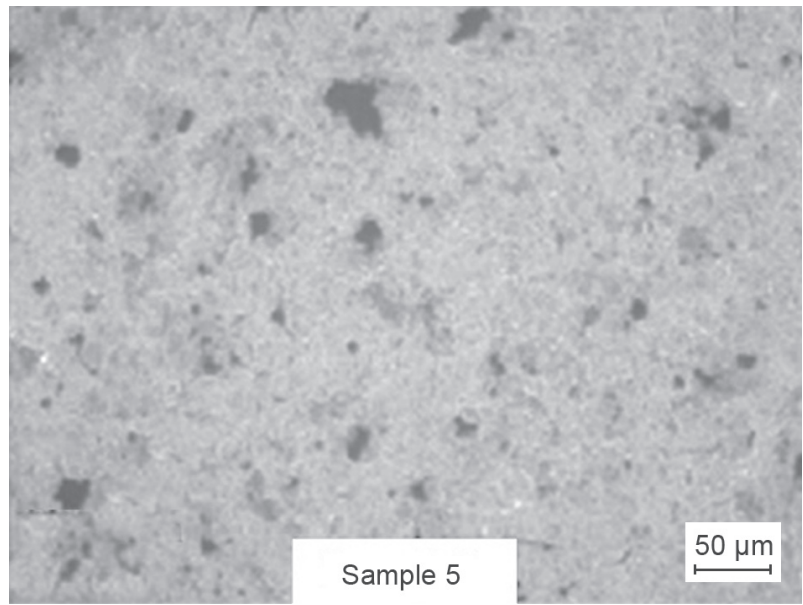

b)

Figure 2. Standard appearance of samples $3\left(\right.$ ratio $\left.\mathrm{Ca} / \mathrm{P}=3 ; \mathrm{pH}=7 ; 5 \mathrm{ml} \cdot \mathrm{min}^{-1}\right)$ and $5\left(\right.$ ratio $\left.\mathrm{Ca} / \mathrm{P}=1.67, \mathrm{pH}=12,5 \mathrm{ml} \cdot \mathrm{min}^{-1}\right)$ after aging (24 hours) using a digital microscope (Dino-Lite Rack - MS34B).

Table 2. The standard appearance of samples 3, 8 and 11 before aging.

\begin{tabular}{|c|c|c|c|c|}
\hline Sample & Ratio $\mathrm{Ca} / \mathrm{P}$ & $\mathrm{pH}$ & $\begin{array}{l}\text { Precipitation rate } \\
\qquad\left(\mathrm{ml} \cdot \mathrm{min}^{-1}\right)\end{array}$ & $\begin{array}{l}\text { Results from projection optical microscope } \\
\text { (MP-1326, Poland) }\end{array}$ \\
\hline 3 & 3 & 7 & 5 & 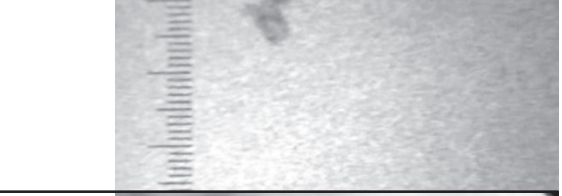 \\
\hline 8 & 1.67 & 7 & 0.5 & \\
\hline 11 & 1.67 & 12 & 0.5 & \\
\hline
\end{tabular}


Influence of precipitation conditions on the synthesis of hydroxyapatite

SEM analysis

Measurement by SEM was performed after sample drying and grinding. The most interesting results was observed for the samples $1-3,5$ and 8 that showed the effect of different $\mathrm{Ca} / \mathrm{P}$ ratio (samples 1-3), $\mathrm{pH}$ (samples 2 and 5) and precipitation rate (samples 2 and 8) on sample morphology.

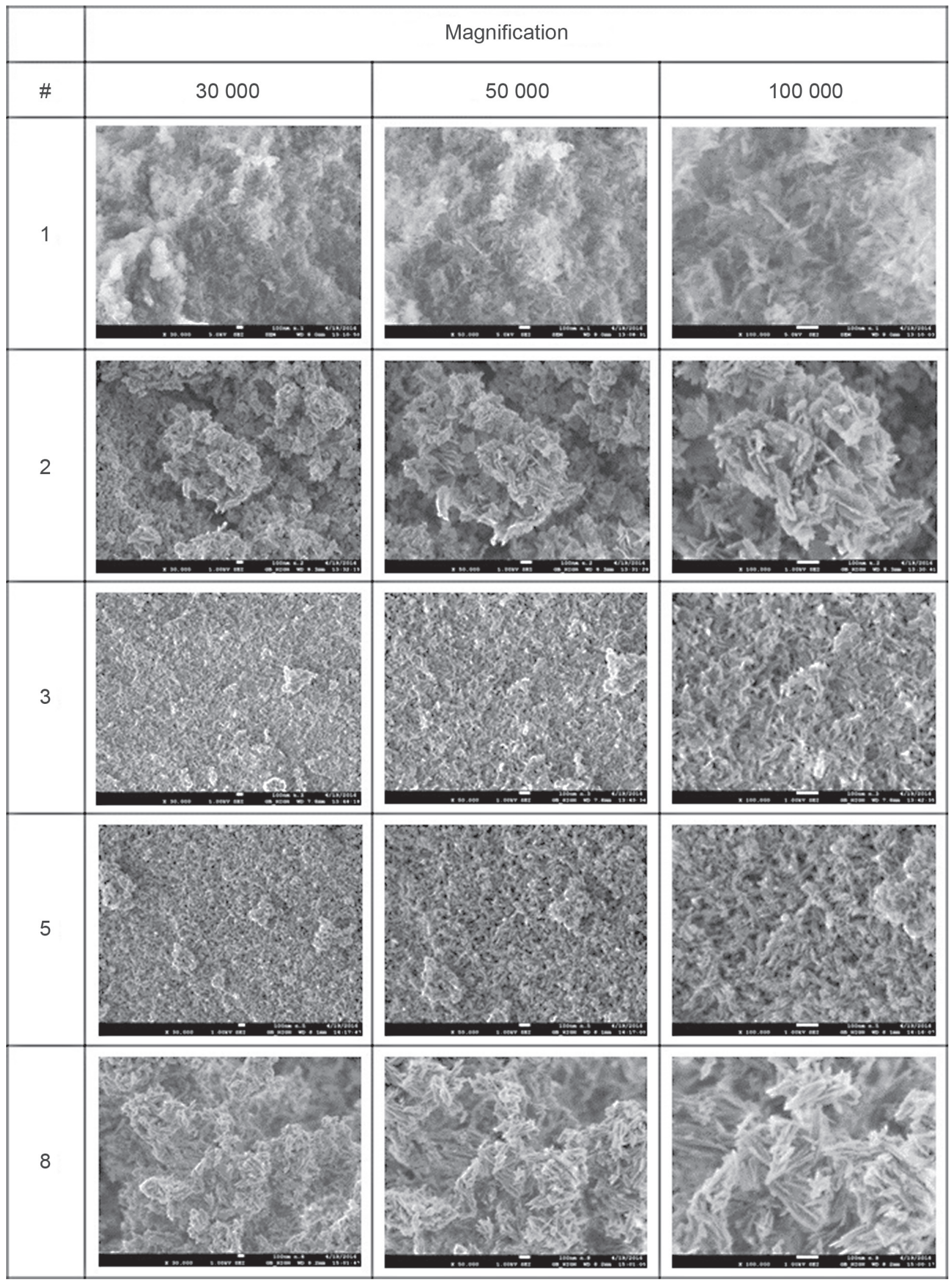

Figure 3. Comparison of samples 1, 2, 3, 5 and 8 at different magnification $(\times 30000 ; \times 50000 ; \times 100000)$. 
Table 3. Crystal size based on SEM images (resolution $\times 100000$ ).

\begin{tabular}{|c|c|c|c|c|c|c|c|}
\hline Sample & $\begin{array}{l}\text { Max. width } \\
\text { (nm) }\end{array}$ & $\begin{array}{l}\varnothing \text { width } \\
(\mathrm{nm})\end{array}$ & $\begin{array}{l}\text { Max. length } \\
\quad(\mathrm{nm})\end{array}$ & $\begin{array}{l}\varnothing \text { length } \\
(\mathrm{nm})\end{array}$ & $\begin{array}{l}\text { Max. thickness } \\
\qquad(\mathrm{nm})\end{array}$ & $\begin{array}{c}\varnothing \text { thickness } \\
(\mathrm{nm})\end{array}$ & Shape of crystals \\
\hline 1 & $<24$ & $\sim 10$ & $<185$ & $\sim 60$ & $<24$ & $\sim 10$ & needle-like shapes \\
\hline 2 & $<240$ & $\sim 120$ & $<240$ & $\sim 120$ & $<20$ & $\sim 10$ & tabular plates \\
\hline 3 & $<50$ & $\sim 25$ & $<80$ & $\sim 40$ & $<10$ & $\sim 5$ & $\begin{array}{l}\text { needle-like shapes, } \\
\text { tabular plates, bulky } \\
\text { formations }\end{array}$ \\
\hline 4 & $<50$ & $\sim 20$ & $<50$ & $\sim 20$ & $<50$ & $\sim 20$ & bulky formations \\
\hline 5 & $<50$ & $\sim 20$ & $<60$ & $\sim 25$ & $<50$ & $\sim 20$ & bulky formations \\
\hline 6 & $<200$ & $\sim 100$ & $<200$ & $\sim 120$ & $<25$ & $\sim 15$ & tabular plates \\
\hline 8 & $<240$ & $\sim 140$ & $<240$ & $\sim 140$ & $<20$ & $\sim 10$ & tabular plates \\
\hline 11 & $<100$ & $\sim 50$ & $<200$ & $\sim 100$ & $<20$ & $\sim 10$ & $\begin{array}{c}\text { needle-like shapes, } \\
\text { tabular plates, } \\
\text { bulky formations }\end{array}$ \\
\hline
\end{tabular}

In order to demonstrate the effect of the $\mathrm{Ca} / \mathrm{P}$ ratio on the particle shape, samples 1, 2 and 3 were selected. These samples were synthesized at different $\mathrm{Ca} / \mathrm{P}$ ratios, at the same precipitation rate $\left(0.5 \mathrm{ml} \cdot \mathrm{min}^{-1}\right)$ and the same $\mathrm{pH}$ (7). The $\mathrm{Ca} / \mathrm{P}$ ratio has been found to have an effect on particle size and shape. Figure 3 compares sample $1(\mathrm{Ca} / \mathrm{P}=1$, needle-like shapes $)$ with sample $2(\mathrm{Ca} / \mathrm{P}=$ 1.67 , tabular plates) and with sample $3(\mathrm{Ca} / \mathrm{P}=3$, needle shapes, bulky formations).

In order to demonstrate the effect of $\mathrm{pH}$ on the morphology of the particles, samples 2 and 5 (Figure 3) were selected which were synthesized at different $\mathrm{pH}$ ratios, the same $\mathrm{Ca} / \mathrm{P}$ ratio (1.67) and precipitation rate $\left(0.5 \mathrm{ml} \cdot \mathrm{min}^{-1}\right)$. Figure 3 shows that the particles of sample 2 at $\mathrm{pH}=7$ are larger tabular plates, the particles of sample 5 at $\mathrm{pH}=12$ are bulkier and smaller.

The influence of precipitation rate on the particle shape is also shown in Figure 3. Samples 2 and 8 were prepared at different precipitation rates, the same $\mathrm{Ca} / \mathrm{P}$ ratio (1.67) and the same $\mathrm{pH}(7)$. The precipitation rate did not have any effect on the shape of the particle.

Based on analysis of samples 1-3, 5 and 8 by SEM, crystallite sizes were also evaluated. Table 3 shows the crystal size determined from scanning electron microscope images at $\times 100000$ resolution.

\section{Particle size distribution}

Particle size distribution of synthesized samples was measured after 24 hours aging with the Mastersizer 2000 MU. Signal was evaluated by Mie scattering. The distribution curves and $\mathrm{d}_{10}, \mathrm{~d}_{50}, \mathrm{~d}_{90}$ and distribution span were obtained. Figure 4 shows the distribution curves of all samples (1-12) for illustration. The width of the distribution ranges from 0.3 to $300 \mu \mathrm{m}$ in particle size range.

Table 4 shows the particle size values $d_{10}, d_{50}, d_{90}$ and the distribution range of all the measured samples. For all samples, the $d_{10}$ value is in the range from 0.8 to
$6.3 \mu \mathrm{m}$, the $\mathrm{d}_{50}$ value is from 1.8 to $16.4 \mu \mathrm{m}$, the $\mathrm{d}_{90}$ value is from 3.6 to $64.7 \mu \mathrm{m}$. The distribution range (span) of all analyzed samples is from 1.45 to 4.66 .

The results indicate the size of the agglomerates and not the real size of the crystals. No trends were found in terms of precipitation rate and $\mathrm{pH}$ to agglomerate size. Some dependence was demonstrated between the $\mathrm{Ca} / \mathrm{P}$ ratio and the mean $\mathrm{d}_{50}$ and span. For samples prepared at a $\mathrm{Ca} / \mathrm{P}=1$ ratio, agglomerates with a high span, distribution width and $\mathrm{d}_{50}(7.2$ to $19.5 \mu \mathrm{m})$ were obtained. This statement is consistent with samples 1, 4 and 10 prepared at this ratio. This shows that the samples prepared at the $C a / P=1$ ratio provide the highest $d_{10}$, $\mathrm{d}_{50}$ and $\mathrm{d}_{90}$ values, as well as the highest span, compared to the $\mathrm{Ca} / \mathrm{P}$ ratio of 1.67 and 3 . Conversely, for samples prepared at a $\mathrm{Ca} / \mathrm{P}=1.67$ ratio, lower $\mathrm{d}_{50}$ values (1.8 $7.7 \mu \mathrm{m})$ were obtained. This assertion is confirmed by samples 2, 5 and 8. It is obvious, samples prepared at a $\mathrm{Ca} / \mathrm{P}$ ratio of 1.67 provide low values of $\mathrm{d}_{10}, \mathrm{~d}_{50}$ and $\mathrm{d}_{90}$ and a lower span value as compared to $\mathrm{Ca} / \mathrm{P}=1$ ratio.

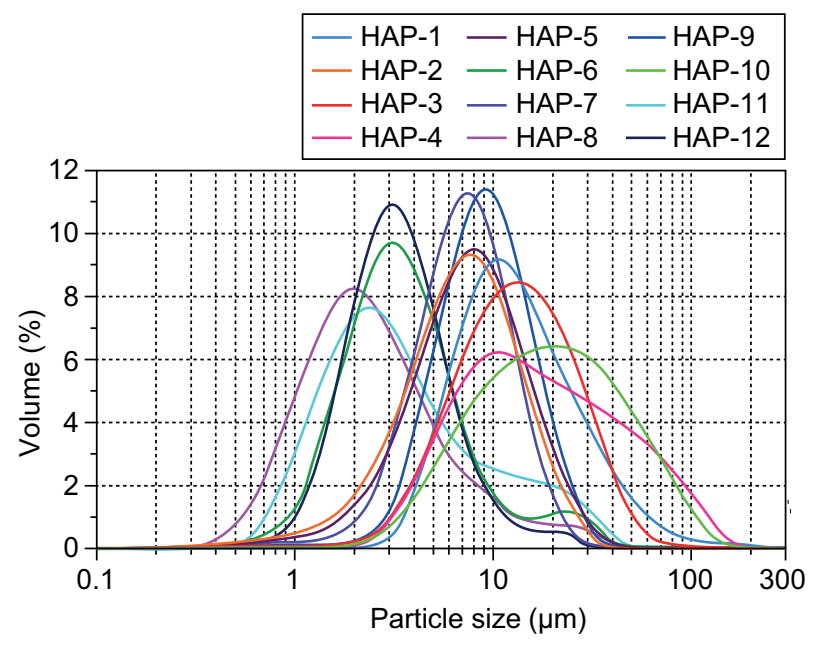

Figure 4. Distribution curves of all synthesized samples. 
For samples prepared at a $\mathrm{Ca} / \mathrm{P}=3$ ratio, lower $\mathrm{d}_{50}$ values ( 3.2 to $13.1 \mu \mathrm{m}$ ) were also obtained. This assertion is confirmed by samples 3, 6, 9 and 12 . It is obvious that the samples prepared at the $\mathrm{Ca} / \mathrm{P}=3$ ratios also provide low values of $d_{10}, d_{50}$ and $d_{90}$ and a lower span value as compared to the $\mathrm{Ca} / \mathrm{P}=1$ ratio.

Table 4. Particle size distribution of all synthesized samples.

\begin{tabular}{ccccc}
\hline & \multicolumn{4}{c}{ Particle size } \\
\cline { 2 - 5 } Sample & $\begin{array}{c}\mathrm{d}_{10} \\
(\mu \mathrm{m})\end{array}$ & $\begin{array}{c}\mathrm{d}_{50} \\
(\mu \mathrm{m})\end{array}$ & $\begin{array}{c}\mathrm{d}_{90} \\
(\mu \mathrm{m})\end{array}$ & span \\
\hline 1 & 5.81 & 12.53 & 34.26 & 2.27 \\
2 & 2.72 & 7.13 & 15.79 & 1.83 \\
3 & 5.21 & 13.06 & 30.81 & 1.96 \\
4 & 5.49 & 16.37 & 64.77 & 3.62 \\
5 & 3.10 & 7.69 & 17.08 & 1.82 \\
6 & 1.55 & 3.37 & 9.14 & 2.25 \\
7 & 3.44 & 7.20 & 13.98 & 1.46 \\
8 & 0.79 & 1.78 & 3.62 & 1.58 \\
9 & 4.59 & 9.19 & 17.96 & 1.45 \\
10 & 6.22 & 19.47 & 59.05 & 2.71 \\
11 & 1.22 & 3.04 & 15.39 & 4.66 \\
12 & 1.64 & 3.26 & 7.12 & 1.68 \\
\hline
\end{tabular}

\section{XRD analysis}

The phase composition of the samples was determined by XRD analysis. Two distinct structures of hydroxyapatite have been identified: monoclinic and hexagonal. Figure 5 shows the diffractogram of sample 1 containing the hydroxyapatite diffraction line $\mathrm{Ca}_{10}\left(\mathrm{PO}_{4}\right)_{6}(\mathrm{OH})_{2}$ with the following parameters: hexagonal crystalline system; space group $\mathrm{P}_{3} / \mathrm{m}$. Figure 5 also shows a diffractogram of sample 2 containing the

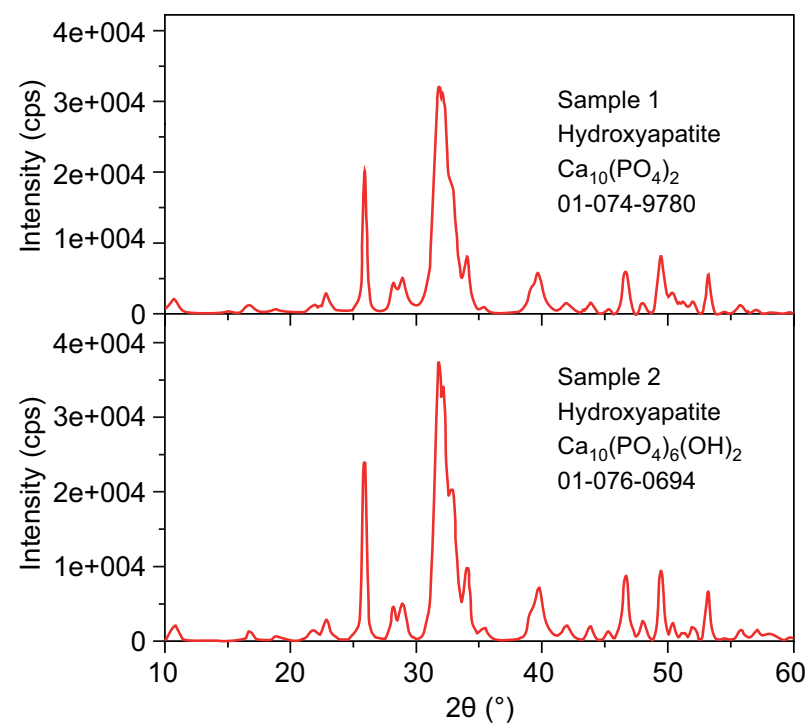

Figure 5. Diffractogram of sample 1 (hexagonal HAP) and 2 (monoclinic HAP). hydroxyapatite diffraction line $\mathrm{Ca}_{10}\left(\mathrm{PO}_{4}\right)_{6}(\mathrm{OH})_{2}$ with the following parameters: monoclinic crystalline system; space group $\mathrm{P} 2{ }_{1} / \mathrm{b}$. The XRD profiles of both structures are almost identical, it means that both crystalline structures are very similar. For this reason, it is very difficult to properly recognize these structures from the XRD profiles of the measured samples. These structural types of hydroxyapatite were selected based on the lowest value of FOM (figure of merit), i.e., based on the best match.

The crystal size was calculated from the diffractogram based on the diffraction line width using the Scherrer equation, Williamson-Hall (WH) [19] and the Halder-Wagner (HW) method [20]. The results are shown in Table 5. Table 5 shows that according to the Scherrer equation, the size of the crystals of hydroxyapatite ranges from 5.1 to $31.4 \mathrm{~nm}$, according to the $\mathrm{H}-\mathrm{W}$ method in the range from 5.3 to $10.8 \mathrm{~nm}$ and according to the Hall method in the range from 6.1 to $10.7 \mathrm{~nm}$. The methods used have shown approximately the same result in the nanocrystalline range. The large difference in crystal size calculated according to the Scherrer equation can be explained by the large difference between the thickness, width, and crystal length.

Table 5. Crystallite size of synthesized hydroxyapatite samples.

\begin{tabular}{cccc}
\hline $\begin{array}{c}\text { Sample } \\
\text { of HAP }\end{array}$ & $\begin{array}{c}\text { Crystallite size } \\
\text { according to } \\
\text { Sherry's equation } \\
(\mathrm{nm})\end{array}$ & $\begin{array}{c}\text { Crystallite size } \\
\text { according to } \\
\text { H-W method } \\
(\mathrm{nm})\end{array}$ & $\begin{array}{c}\text { Crystallite size } \\
\text { according to } \\
\text { Hall method } \\
(\mathrm{nm})\end{array}$ \\
\hline 1 & $6.5-28.4$ & $7.03(1.7)$ & $6.4(1.2)$ \\
2 & $5.9-25.5$ & $10.4(0.5)$ & $9.3(2.7)$ \\
3 & $6.68-28.0$ & $7.4(0.5)$ & $8.5(3.4)$ \\
4 & $5.1-18.0$ & $7.0(0.5)$ & $7.8(2.3)$ \\
5 & $6.22-16.1$ & $5.3(0.4)$ & $9.0(5.7)$ \\
6 & $7.2-25.6$ & $6.27(1.1)$ & $6.7(1.2)$ \\
7 & $8.9-31.4$ & $10.75(1.3)$ & $10.7(1.3)$ \\
8 & $8.5-29.6$ & $7.46(1.7)$ & $8.9(1.6)$ \\
9 & $8.06-30.3$ & $7.31(1.1)$ & $8.8(1.6)$ \\
10 & $0.54-16.62$ & $6.6(0.5)$ & $6.8(1.8)$ \\
11 & $6.78-19.1$ & $5.57(1.8)$ & $8.2(2.4)$ \\
12 & $6.41-22.5$ & $6.7(0.3)$ & $6.1(1.7)$ \\
\hline
\end{tabular}

Comparison of the crystal size results obtained from SEM and XRD analysis revealed that the minimum dimensions of SEM analysis (Table 3) were comparable to the maximum dimensions of XRD analysis (Table 5). In general, SEM analysis shows a larger crystal size. This phenomenon can be explained by the fact that for the maximum crystal size analysis the largest particles that are visible in the SEM images are selected. The contributions of these largest particles to the average crystal size are small. Further, this phenomenon can be explained by the fact that the largest crystals visible in the SEM figures are made up of smaller crystals. 


\section{CONCLUSION}

The goal of this study was to find suitable precipitation conditions $(\mathrm{Ca} / \mathrm{P}$ ratio, $\mathrm{pH}$ and precipitation rate) for the synthesis of hydroxyapatite and determine the effect of precipitation conditions on the synthesis of pure hydroxyapatite (HAP; $\left.\mathrm{Ca}_{10}\left(\mathrm{PO}_{4}\right)_{6}(\mathrm{OH})_{2}\right)$.

By SEM analysis, the effect of $\mathrm{Ca} / \mathrm{P}$ ratio and $\mathrm{pH}$ of sample particles was determined. Conversely, the effect of the precipitation rate on ammonium dihydrogen phosphate was not demonstrated. Based on the results, it can be concluded that selected synthetic conditions are suitable for the formation of crystalline hydroxyapatite. The most suitable precipitation conditions for the formation of the pure hydroxyapatite phase is $\mathrm{Ca} / \mathrm{P}=1$ which provides the best result with respect to crystallinity, particle shape and size, particle size distribution and phase composition. Sample 1 was synthesized at a ratio $\mathrm{Ca} / \mathrm{P}=1, \mathrm{pH}=7$ and a precipitation rate of $5 \mathrm{ml} \cdot \mathrm{min}^{-1}$. These conditions will be used for the synthesis of pure hydroxyapatite that will be studied for corrosion inhibitor properties with respect to pigmentary use. By contrast, less suitable precipitation conditions at the $\mathrm{Ca} / \mathrm{P}=3$ ratios were demonstrated.

\section{Acknowledgments}

This work has been supported by IGU University of Pardubice (SGS_2017_007).

\section{REFERENCES}

1. Elliott J.C. (1994). Structure and chemistry of the apatites and other calcium orthophosphates. 2 vyd. Elsevier.

2. Rivera-Muñoz E.M. (2011). Hydroxyapatite - based materials: synthesis and characterization. Intech.

3. Friedman H (2014). Complete information guide to rock, minerals and gemstones: The apatite mineral group. Minerals.net: The mineral and gemstone kingdom. http:// www.minerals.net/mineral/apatite.aspx.

4. Gorodylova N., Dohnalová Ž., Šulcová P., Bělina P., Vlček M (2016): Influence of synthesis conditions on physicochemical parameters and corrosion inhibiting activity of strontium pyrophosphates $\mathrm{SrM}^{\mathrm{II}} \mathrm{P}_{2} \mathrm{O}_{7}\left(\mathrm{M}^{\mathrm{II}}=\mathrm{Mg}\right.$ and $\mathrm{Zn)}$. Progress in organic coating, 93, 77-86. doi: 10.1016/j. porgcoat.2016.01.004

5. Kalenda P., Veselý D., Antoš P (2003). Koroze a protikorozni ochrana kovových materiálů. 1. vyd. Univerzita Pardubice.

6. Huang Y., Hao M., Nian X., et al. (2016): Strontium and copper co-substituted hydroxyapatite-based coatings with improved antibacterial activity and cytocompatibility fabricated by electrodeposition. Ceramics International, 42, 11876-11888. doi: 10.1016/j.ceramint.2016.04.110

7. Chetty A., Wepener I., Marei MK., Kamary YE., Moussa RM (2013). Hydroxyapatite: synthesis, properties and applications. Nova Science Publishers, Inc.

8. Coreño A.J., Coreño A.O., Cruz R.J.J., Rodríguez C.C. (2005): Mechanochemical synthesis of nanocrystalline carbonate-substituted hydroxyapatite. Optical Materials, 27, 1281-1285. doi: 10.1016/j.optmat.2004.11.025

9. Arita I.H., Castano V.M., Wilkinson D.S. (1995): Synthesis and processing of hydroxyapatite ceramic tapes with controlled porosity. Journal of Materials Science, 6, 19-23. doi: 10.1007/BF00121241

10. Akao M., Aoki H., Kato K. (1981): Mechanical properties of sintered hydroxyapatie for prothetic applications. Journal of Materials Science, 16, 809-812. doi: 10.1007/ BF02402799

11. Kong LB., Ma J., Boey F (2002): Nanosized hydroxyapatite powders derived from coprecipitation process. Journal of Materials Science, 37, 1131-1134. doi: 10.1023/ A:1014355103125

12. Zhang X., Vecchio K. S (2007): Hydrothermal Synthesis of Hydroxyapatite Rods. Journal of Crystal Growth, 308, 133-140. doi: 10.1016/j.jcrysgro.2007.07.059

13. Wang J., Shaw LL (2009): Synthesis of high purity hydroxyapatite nanopowder via sol-gel combustion process. Journal of Materials Science, 20, 1223-1227. doi: 10.1007/ s10856-008-3685-x

14. Jillavenkatesa A (1998): Sol-gel processing of hydroxyapatite. Journal of materials science, 33, 41114119. doi: 10.1023/A:1004436732282

15. Yang Y., Ong J.L., Tian J (2002): Rapid sintering of hydroxyapatite by microwave processing. Journal of Materials Science Letters, 21, 67-69. doi: 10.1023/A:1014250813564

16. Safronova T.V., Shekhirev M.A., Putlyaev V.I. (2007): Ceramics Based on Calcium Hydroxyapatite Synthesized in the Presence of PVA. Glass and Ceramics, 64, 408-412. doi: 10.1007/s10717-007-0102-8

17. Vazquez CG., Barba CP., Munguia N (2005): Stoichiometric hydroxyapatite obtained by precipitation and sol gel processes. Revista Mexicana de Fisica, 51, 284-293.

18. Hermassi M., Valderrama C., Dosta J., Cortina J.L., Batis N.H. (2015): Evaluation of hydroxyapatite crystallization in a batch reactor for the valorization of alkaline phosphate concentrates from wastewater treatment plants using calcium chloride. Chemical engineering journal, 267, 142-152. doi: 10.1016/j.cej.2014.12.079

19. Kalita A., Kalita M.P.C. (2017): Williamson-Hall analysis and optical properties of small sized $\mathrm{ZnO}$ nanocrystals. Physica. E, Low-dimensional systems and nanostructures, 92, 36-40. doi: 10.1016/j.physe.2017.05.006

20. Motevalizadeh L., Heidary Z., Abrishami M.E. (2014): Facile template-free hydrothermal synthesis and microstrain measurement of $\mathrm{ZnO}$ nanorods. Bulletin of materials science, 37, 397-405. doi: 10.1007/s12034-014-0676-Z 